\section{IJIKMMENA}

\section{1,2}

113

\title{
CREATING A SUSTAINABLE BIOTECHNOLOGY SECTOR IN THE ARAB WORLD: LESSONS FROM THE SWEDISH CASE
}

\author{
Adli Abouzeedan' \\ University of Gothenburg, Sweden \\ Maureen McKelvey ${ }^{2}$ \\ University of Gothenburg, Sweden
}

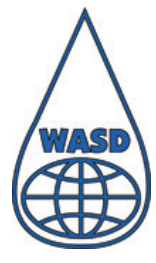

International Journal of Innovation and Knowledge Management in Middle East \& North Africa Vol. 1 No. 2, 2012

\begin{abstract}
Purpose: The purpose of this paper is to present and analyse the strategies used in building the Swedish biotechnology sector. Developing as well as developed countries need access to a strong and vitalised biotechnology industry for their economic and social progress. In Sweden, the biotechnology sector is playing an important role in regional and national economic development and growth. This can serve as an example of trends in other developed countries.

Design/methodology/approach: This paper discusses alternative business models and the setting of the industry, which has traditionally been highly dependent upon basic research, but also upon demand and markets. We then use this analysis to draw out general lessons and recommendations that may assist the Arab countries in their efforts to build a sustainable biotechnology sector, with focus on health and medical applications.

Practical implications: The findings offer valuable knowledge for use in developing the biotechnology sector in the Arab world.
\end{abstract}

${ }^{1}$ Dr. Adli Abouzeedan, Institute of Innovation and Entrepreneurship, School of Business, Commerce and Law, University of Gothenburg, Gothenburg, SWEDEN, Email: adli.abouzeedan@gmail.com

${ }^{2}$ Prof. Maureen McKelvey, Institute of Innovation and Entrepreneurship, School of Business, Commerce and Law, University of Gothenburg, Gothenburg, SWEDEN, Email: Maureen.McKelvey@handels.gu.se 
Findings: Our analysis, showed that in order to use the Swedish biotechnology model in the Arab world, the additive solution should be used in accordance with the IBAM. This means engaging the whole region in the process rather than focusing on single countries.

Originality/value - We hope that this work provides strategies for Arab planners in transferring the guided experiences of other nations into their countries.

Creating a

Sustainable Biotechnology

Sector in the Arab World

Keywords: Sustainable development; Biotechnology; Pharmaceutical industry; Healthcare; Business models; System capital; Innovation capital; MENA; Arab world; Arab Spring; Innovation Balance Matrix; IBAM

\section{INTRODUCTION}

The biotechnology sector is a vital one in any economy, especially in relation to health and medical applications. Biotechnology application in healthcare requires a sound R\&D (Research and Development) research policy, combined with good business models. Biotechnology is defined in different ways. One definition proposed by the Organization for Economic Cooperation and Development (OECD), as stated in Brink et al. (2007, p. 733) is as follows:

"Biotechnology is the application of scientific and engineering principles to the processing of materials by biological agents to provide goods and services."

Benefiting from the experiences of other nations will help developing countries as they strive to create and expand a vibrant and effective biotechnology industry with particular focus on healthcare applications. The reason for our emphasis on the Arab region in the Middle East and North Africa (MENA) is related to the fact that most other non-Arab countries in the region have developed their economies using successful assimilation and wise implementation of the existing models, while the Arab countries are still struggling with 
IJIKMMENA these issues. Learning from other nations and their experi1,2 ences, as opposed to dangerous experimentation, is a wise development strategy. Sweden has developed a stable biotechnology sector, where biotechnology firms for healthcare have been contributing to the worldwide growth of this sector on a continuous basis. Swedish companies in pharmaceuticals and biotech have introduced a number of major drugs to the market in the last few decades. We believe that lessons from this Swedish experience can be extended to the Arab world.

Rickne and Jacobsson (1996) explored the role played by new technology-based firms in the development of new industrial sectors in Sweden. Evolutionary economics suggest that there are particular aspects of knowledge that are fundamentally attached to individuals and firms, while other types of knowledge are shared at the aggregate level (McKelvey, 1998). Firms in the early stage of product development tend to benefit more from networks with universities (McKelvey, 2008). An important factor that enhances firms' abilities to have a strong network structure is their capacity to build strategic alliances with other enterprises across the globe. The information technology revolution increased this ability to build such strategic alliances (Abouzeedan and Busler, 2007a) and facilitated the invention of the internetisation management paradigm to operate the alliance structure among partners (ibid).

This paper is exploratory in nature. The first section is a general introduction and in the second section, we discuss the challenges in developing new sectors in the Arab world. In the third section, we look at the Swedish biotechnology model before analysing the local conditions in the Arab countries and the adaption of the Sweden model in that region in the fourth section. The conclusions are drawn in the fifth section. 
Creating a

Sustainable

Biotechnology

Sector in

the Arab

World

116 cable to the case of Arab countries. Abouzeedan and Busler (2007b) analysed economic conditions in that part of the world. Their conclusions were that the Arab countries suffer from two problems in structuring their economic modelling. Firstly, over decades, Arab countries have tended to use ineffective methods of economic operations, which have a negative impact on their efforts to become global economic players. Secondly, Arab countries have applied obsolete economic planning schemes, which are based on less participation in the innovative and entrepreneurial activities of the global arena (see Table 1). Abouzeedan and Busler (2006) argued that the growth and vitality of an economy is dependent on the abundance of innovation activities. The two writers proposed the term "innovation capital" to express the degree of inventiveness, commercialization of new products or services and innovativeness in a society. The types of capital are: human capital, financial capital and system capital (ibid) and open innovation (Abouzeedan et al., 2009).

Utilizing the Innovation Balance Matrix (IBAM) tool, Abouzeedan and Busler (2006) divided the Arab countries into three groups. The first group has a higher level of human capital. The countries in this group are populous and lack a good structure to promote entrepreneurial and innovation activities (the so-called system capital). This group of countries also lacks financial resources to utilise in their development drives. Among the members of this group are countries like Egypt, Morocco, Tunisia, Yemen, Sudan and Algeria. Algeria 
IJIKMMENA has a better financial situation due to its revenues from natu1,2 ral gas exploitation and exportation activities (ibid).

The second group of Arab countries has a high level of financial resources due to oil and gas exploitation and exportation activities. These countries have lower levels of governmental corruption, which makes the financial resources from the oil industry available for economic development. The fact that they are less populous regions of the Arab region provides them with an advantage. However, this group of countries lacks a good pool of human resources. They are basically dependent on importing a qualified foreign work force, with associated high salaries and designated costs. These countries also lack long-term planning in their immigration and nationalization polices, and are deficient in strategies aiming at absorbing this workforce through generous immigration schemes (Khouja and Sadler, 1979). In addition, the systems of these countries do not promote innovation and entrepreneurial drive, expressed as system capital. Members of this group are mainly located in the Gulf region and North Africa. They include the GCC countries as well as Libya.

The third group of Arab countries has a good tradition of entrepreneurial drive and innovativeness, i.e. a high level of system capital, but lacks both a high level of qualified human resources and financial resources. These include Lebanon, Jordan, Syria, Palestine and Iraq. When we say that these countries lack a large human pool, we mean that in a relative way as compared to populous countries like Egypt. One needs to stress that the situation in some of these countries in the last couple of years has been altering drastically via major military conflicts and internal civil unrest. However, historically, countries like Iraq and Syria have enjoyed a good potential for economic growth and a tradition of entrepreneurial drive and inventiveness (Abouzeedan and Busler, 2006, 2007b). 
The current turbulence in the region due to unrest and conflicts, referred to as the Arab Spring, is understandable in light of the desire of the new generation of Arab people to live in a dignified and respectable way, in a society that promotes their human rights and their right to choose their representatives and leaders. This is true throughout the entire region. We stress that the Arab world of today is more dynamic and turbulent than was anticipated, but the basic analysis of the IBAM tool still holds strong (see Abouzeedan and Busler, 2006, 2007b).

\begin{tabular}{|c|c|c|c|}
\hline Factor & Impact & Explanation & \\
\hline $\begin{array}{l}\text { Abundance of basic non- } \\
\text { human resources (e.g. oil, } \\
\text { minerals, land suitable for ag- } \\
\text { riculture) }\end{array}$ & Positive & $\begin{array}{l}\text { The role of global resource sup- } \\
\text { plier is satisfied }\end{array}$ & \\
\hline $\begin{array}{l}\text { Large number of young, edu- } \\
\text { cated people (youthful popu- } \\
\text { lation) }\end{array}$ & Positive & $\begin{array}{l}\text { The role of global manpower } \\
\text { supplier is satisfied. }\end{array}$ & \\
\hline $\begin{array}{l}\text { Methods of economical } \\
\text { operation }\end{array}$ & Negative & $\begin{array}{l}\text { The role of the ineffective glob- } \\
\text { al economical player is satisfied. }\end{array}$ & \\
\hline $\begin{array}{l}\text { Great historical performance } \\
\text { (culture, religion, science, } \\
\text { etc) }\end{array}$ & Positive & $\begin{array}{l}\text { The role of global educator, re- } \\
\text { synthesizer, criticizer is satisfied }\end{array}$ & \\
\hline $\begin{array}{l}\text { Economic planning and ac- } \\
\text { tive participation }\end{array}$ & Negative & $\begin{array}{l}\text { The role of victimized, losing } \\
\text { global player is satisfied }\end{array}$ & \\
\hline $\begin{array}{l}\text { Dynamism due to instability, } \\
\text { turbulence and re-examin- } \\
\text { ing }\end{array}$ & Positive & $\begin{array}{l}\text { The role of potential futuristic } \\
\text { global player is satisfied }\end{array}$ & $\begin{array}{l}\text { Table I: } \\
\text { Basic economical }\end{array}$ \\
\hline \multicolumn{3}{|c|}{ Source: Abouzeedan and Busler (2007b) } & $\begin{array}{l}\text { world and their } \\
\text { impact on }\end{array}$ \\
\hline & & & Globalization \\
\hline
\end{tabular}


IJIKMMENA

\section{1,2}

\section{THE SWEDISH MODEL OF BIOTECHNOLOGY}

All innovation systems involve the creation, diffusion and utilisation of knowledge (Carlsson et al., 2002). The function of an innovation system is to generate, diffuse and utilise technology (ibid). For this, actors in the innovation system need to accumulate and possess certain abilities and capabilities. There are four types of capabilities that define the ability of the actor, whether an individual or an organization, to identify and exploit business opportunities. These include: selective (or strategic) capabilities, organizational (integrative or coordinating) capabilities, functional capabilities and learning (or adaptive) capabilities (Carlsson et al., 2002).

One important component in building a solid, sustainable technology sector is to create business models that are able to encompass firms' activities and assist them in their efforts to be both effective (i.e. doing the right things), and efficient (i.e. doing things in the right way). This is why changes in the innovation system should promote the search into new business models that are more responsive to the needs of the firm in the new economic environments as technology shifts ground and focus. That in turn requires a higher level of engagement from the actors involved in promoting technological development in society (McKelvey, 2008). Innovation systems can be national, regional, sectoral or technological (Carlsson et al., 2002). Firms active in health biotechnology have to integrate technological advances in the field with specific application in areas of medicine (McKelvey, 2008).

The Swedish pharmaceutical sector, which encompassed six large firms at the end of the 1970s, ended up, after a series of merges, with two major firms: AstraZeneca and Pfizer (Alm, 2004). As of 2009, the Swedish 
biotechnology sector employed more than 16,200 in 285 companies (Sandström et al., 2011). The largest portion of this workforce (57.3 per cent) is in drug discovery and development (ibid). After that comes medical biotechnology (13.9 per cent) followed by biotechnology tools and supplies (13 per cent) (ibid). The rest of the biotechnology applications utilise the remaining 15 per cent of the

Creating a Sustainable Biotechnology Sector in the Arab World 120 employment force in the sector (ibid). Most of the smaller businesses of the biotechnology sector in Sweden are within the food and related biotechnology applications (ibid). Knowledge relevant to economic development can be either codified knowledge or tacit knowledge (McKelvey, 1998). Both types of knowledge are needed for a nation to borrow a specific successful business model. Currently there are two predominant models for biotechnology applied in the health sector: the classical biotechnology business model and the vertically-integrated firm (ibid).

In order to develop specific areas in biotechnology, the actors concerned with innovation systems rely on the experimentation process. At the micro level, this involves the utilisation of resources and knowledge skills to develop and use technology (Brink et al., 2007). The dynamic properties of an innovation system include robustness, flexibility and the ability to generate change and respond to changes in the environment (Carlsson et al., 2002). Various systems of analysis are used in innovation studies, including input/output analysis, development blocs, national innovation systems, the diamond concept, sectoral innovation systems, local industrial systems, technological systems and competence blocs (ibid). In this work we are closer to the technological systems concept (see Carlsson, 1995, 1997) than any other concept of analysis. 


\section{IJIKMMENA LOCAL CONDITIONS IN THE ARAB COUNTRIES AND 1,2 ADAPTION OF THE SWEDISH MODEL}

As we argued in the second section, the Arab region has specific economic conditions, which are summarized in Table 1. This analysis shows that there are some major economic factors hindering participation by the Arab world in the growth of the world economy. One way to remedy these deficiencies is by re-examining them while taking into account the existing local conditions.

In this paper, we argue that the biotechnology sector in Sweden is characterized by the following: strong connection to the $R \& D$ activities at academic institutions, coupling to a quality-focused large public healthcare sector, publicly financed large health sector, drug production that is outsourced outside Sweden and an R\&D based in Sweden. These characteristics of the Swedish model are not applicable to the Arab countries except for the existence of a publicly financed sector. This supports our view that the local conditions need to be altered to match the requirements of the Swedish model. The previous works of Abouzeedan and Busler (2006, 2007b) already point to the fact that any economic model wishing to succeed in the Arab world needs to deal with the region as a whole and not via the engagement of individual countries. However, we need to break down the analysis at the Arab group level in order to better understand how the Swedish model can be copied (see Table 2). 


\begin{tabular}{llll}
$\begin{array}{l}\text { Characteristics of the } \\
\begin{array}{l}\text { Swedish biotechnology } \\
\text { model }\end{array}\end{array}$ & $\begin{array}{l}\text { Relevance to } \\
\text { group (1) }\end{array}$ & $\begin{array}{l}\text { Relevance to } \\
\text { group (2) }\end{array}$ & $\begin{array}{l}\text { Relevance to } \\
\text { group (3) }\end{array}$ \\
\hline $\begin{array}{l}\text { Strong connection to the } \\
\text { R\&D activities at academ- } \\
\text { ic institutions }\end{array}$ & High & Low & High \\
$\begin{array}{l}\text { Coupling to a quality } \\
\text { \& focused large public } \\
\text { healthcare sector }\end{array}$ & High & High & High \\
$\begin{array}{l}\text { Publicly financed large } \\
\text { health-care sector }\end{array}$ & Low & Low & Low \\
$\begin{array}{l}\text { Drug production is out- } \\
\text { sourced outside Sweden }\end{array}$ & High & Low & High \\
$\begin{array}{l}\text { R\&D is based in Sweden } \\
\text { Righ }\end{array}$ & Low & High \\
\hline
\end{tabular}

Table 2:

Relevance of the characteristics of the Swedish model to the various groups of countries within the Arab world

\section{Relevance of the Swedish model to the first group of Arab countries}

The relevance of the first characteristic of the Swedish model, i.e. the strong connection to the $R \& D$ activities at academic institutions, is high. These countries enjoy a vital and experienced workforce in which most of the experts are educated and trained at the top universities and academic institutions of the world. The coupling to a quality and focused large public healthcare sector is also high, as the pool of human capital in these countries is able to provide skillful individuals. This, in turn, can elevate the quality of the healthcare sectors of these countries. In addition, the outsourcing of drug production outside Sweden is of high relevance to this group, as the possibility of low cost production in these countries is feasible. The countries of this group have a better level of $R \& D$ 
IJIKMMENA than other Arab countries. This makes cooperation with 1,2

$R \& D$ facilities, whether based in Sweden or at one or more of these Arab countries, highly relevant. However, again, financing such activities will be hard due to lack of resources, and in addition, the systems are inefficient because of the low level of system capital. This emphasizes the role of the additive solution proposed using the IBAM tool (Abouzeedan and Bulser, 2006).

\section{Relevance of the Swedish model to the second group of Arab countries}

The only characteristic of the Swedish model with high relevance to the second group of Arab countries is the coupling to a quality and focused large public healthcare sector. The other characteristics of the Swedish model, such as strong connection to the $R \& D$ activities at academic institutions, outsourcing of drug production outside Sweden and R\&D allocation in Sweden, are low.

\section{Relevance of the Swedish model to the third group of Arab countries}

The only characteristic of the Swedish model with low relevance to the third group of Arab countries is a publically financed large healthcare sector. The other characteristics have a high level of relevance, including the following: a strong connection to the R\&D activities at academic institutions, coupling to a quality and focused large public healthcare sector, outsourcing drug production outside Sweden and R\&D based in Sweden. In all three groups, the relevance of the publicly financed large healthcare sector to the application of the Swedish model to the Arab countries is low. Thus, this factor does not hinder the implementation of the Swedish model. In general, the high relevance of a characteristic to the model 
implies a challenge to be dealt with. In contrast, a low level of relevance indicates suitable conditions in relation to the stated characteristic.

Creating a

Sustainable

Biotechnology

Sector in

the Arab

World

In Sweden, the efforts of many years of experimentation have resulted in a sound biotechnology, pharmaceutical and healthcare sector. Transferring the experience from that success story could be beneficial to other countries. The Arab world could benefit from the Swedish model in the areas of biotechnology and healthcare. In this paper, we argued that the Swedish model provides a good platform for creating an effective, sustainable and feasible structure and strategy to use. However, our analysis shows that implementing the model requires coordination of the effort between the individual Arab countries to ensure success. For the Swedish model to be implemented optimally in the Arab world, it has to be tested at the level of the whole region and not only in single countries. This does not mean that the model cannot be applied in individual Arab countries, only that the results will be less certain, as indicated by the IBAM analysis.

\section{BIOGRAPHY}

Dr. Adli Abouzeedan is a visiting researcher at the Institute of Innovation \& Entrepreneurship, University of Gothenburg, Sweden. Abouzeedan holds a PhD degree in innovation and entrepreneurship from Linköping University, Sweden in 2011. He has written extensively in the fields of small firm performance, innovation in SMEs, new paradigms in management such as internetisation management, characteristics of e-globalized economy, financing of SMEs and entrepreneurial models of innovation empowerment. His publications have appeared in peer-reviewed journals such as Journal 
IJIKMMENA of International Entrepreneurship, Journal of Enterprising Culture 1,2 and Global Business Review. Abouzeedan also runs consulting activities as the managing director of Atlanteia Consulting, based in Gothenburg, Sweden.

Prof. Maureen McKelvey is professor of Innovation and Industrial Management at the Institute of Innovation \& Entrepreneurship, University of Gothenburg, Sweden. She has written extensively on the business and economics of biotechnology, including OECD reports, articles and several books with Oxford University Press and Edward Elgar publishers. She has expertise in innovation management issues, especially the interaction between business models and firm strategy with changing external conditions in the 'innovation system'.

\section{REFERENCES}

Abouzeedan, A. and Busler, M. (2006), "Innovation Balance Matrix: an application in the Arab Countries", World Review of Entrepreneurship, Management and Sustainable Development Vol. 2 No. 3, pp. 270-280.

Abouzeedan, A. and Busler, M. (2007a), "Internetisation Management: The Way to Run the Strategic Alliances in the E-globalization Age", Global Business Review, Vol. 8 No. 2, pp. 303-321.

Abouzeedan, A. and Busler, M. (2007b), "Entrepreneurial Policies and the Innovation Balance Matrix: The Case of the Arab Countries", in Allam Ahmed (ed.), Science, Technology and Sustainability in the Middle East and North Africa, Vol. 1, pp. 158-175.

Abouzeedan, A., Busler, B. and Hedner, T. (2009), "Managing Innovation in a Globalized Economy 
- Defining the Open Capital”, in Allam Ahmed (ed.), World Sustainable Development Outlook, Chapter 30, pp. 287-294.

Creating a

Sustainable

Biotechnology

Sector in the Arab

World

Process: A Study of Biotechnology Firms in Sweden, Ph. D

Thesis, Linköping University.

Brink, J, L. Dahlander and McKelvey, M. (2007),

"Developing capabilities: An analysis of biotechnology in two regions in Australia and Sweden”, European Planning Studies, Vol.15 No. 6, pp. 727-751.

Carlsson, B. (ed.), (1995), Technological Systems and Economic

Performance - the Case of Factory Automation, Kluwer

Academic Publishers, Boston, Dordrecht, London.

Carlsson, B. (ed.), (1997), Technological Systems and Industrial dynamics, Kluwer Academic Publishers, Boston, Dordrecht, London.

Carlsson, B., S. Jacobsson, M. Holmen and Rickne, A.

(2002), "Innovation systems: analytical and methodological issues", Research Policy Vol.31, pp. 233-245.

Khouja, M. W. and Sadler, P. G. (1979), The Economy of

Kuwait: Development and Role in International Finance, The Macmillan Press Ltd, London, UK.

McKelvey, M. (1998), "Evolutionary innovations: learning, entrepreneurship and the dynamics of the firm", Journal of Evolutionary Economics Vol.8, pp. 157-175. 
IJIKMMENA McKelvey, M. (2008), OECD International Futures Project 1,2 on "The Biotechnology to 2020: Designing a Policy Agenda”, OECD Multi-Disciplinary Issues, International Futures Programme.

Rickne, A, and Jacobsson, S. (1996), "New technology-based firms - an exploratory study of technology exploitation and industrial renewal", International Journal of Technology Management, Vol.11 No. 3/4, pp. 238-256.

Sandström, A., Dolk T. and Dolk, B. (2011), Life science companies in Sweden - including a comparison with Denmark, VINNOVA ANALYSIS, VA 2011:03 (ISBN: 978-91-86517-32-8) 
